International Journal of Social Sciences and Humanities
Available online at http://sciencescholar.us/journal/index.php/ijssh
Vol. 3 No. 2, August 2019, pages: 112 127
e-ISSN: 2550-7001, p-ISSN: 2550-701X
https://doi.org/10.29332/ijssh.v3n2.298

\title{
Effect of Fiscal Decentralization Policy of Regional Economic Imbalances towards Economy Growth in Eastern Indonesia
}

\author{
Arung Lamba ${ }^{a}$, Paulus K. Allo ${ }^{b}$, Ramasoyan Arung Lamba ${ }^{c}$ \\ Article history: Received 27 December 2018, Accepted: 30 April 2019, Published: 26 July 2019
}

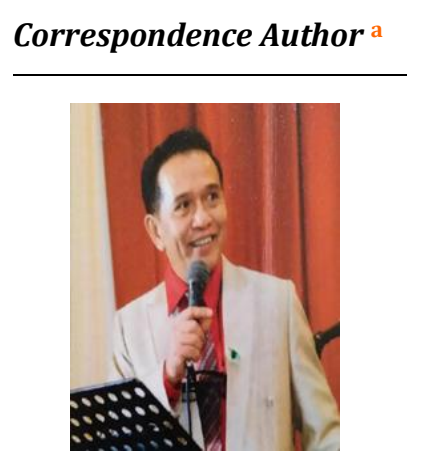

Keywords

eastern Indonesia; economy;

fiscal decentralization; policy;

regional growth;

\begin{abstract}
The current research aimed at analyzing and knowing (1) the influence of fiscal decentralization policy towards economic growth in eastern Indonesia and (2) the influence of fiscal decentralization policy towards regional imbalances decline in eastern Indonesia. In order to reach the aims, panel data was analyzed. It was analyzed by accommodating information that related to crosssection variables and time series. The panel data, substantially, is expected to be able to decrease the problems of omitted-variables. Furthermore, regression effect analysis was applied for estimating the econometric model. The results of the current research have shown that: (1) fiscal decentralization policy influences growth of the regional economy, and (2) the relationship of fiscal decentralization policy with regional imbalance has confirmed that the decentralization fiscal has not got any ability to reduce the imbalances economy of eastern Indonesia.
\end{abstract}

e-ISSN: 2550-7001, p-ISSN: 2550-701X ${ }^{\odot}$ Copyright 2019. The Author. SS Journals Published by Universidad Técnica de Manabí. This is an open-access article under the CC BY-SA 4.0 license (https://creativecommons.org/licenses/by-sa/4.0/) All rights reserved.

\section{Contents}

Abstract. 112

1. Introduction. 113

2. Materials and Methods .

3. Results and Discussions 118

3.1 Decentralization Fiscal Impact on Regional Economy Growth 118

3.2 Impact of Fiscal Decentralization toward Regional Imbalance 121

4. Conclusion 125

Acknowledgements... 125

References ..... 126

Biography of Authors . 127

a Universitas Cenderawasih, Papua, Indonesia

b Universitas Cenderawasih, Papua, Indonesia

c Universitas Cenderawasih, Papua, Indonesia 


\section{Introduction}

Since 2001, Indonesia has formally run fiscal decentralization policy, that is by shifting more responsibilities for expenditures and/or revenues to lower levels of government. One important factor in determining fiscal decentralization is the extent to which subnational entities are given autonomy to determine the allocation of their expenditures, especially in economic affairs. By the time, topics of relationship between fiscal decentralization policy and regional economic imbalances have been interested.

The issue of autonomy and decentralization in Indonesia is based in Indonesian Law No. 33 the Year 2004 concerning balance finance between the central government and regional government. The substance of the law is that the regional government has been given more authority in managing its government and its finance. It is hoped that regional development can be processed related to regional aspirations, needs, etc. It is believed that the development will impact the regional economy, which will also improve welfare community in the area. The improvement itself is based on implementation government funding sources which include revenue, original local government revenue, balanced funds, and other regional incomes.

Next, to reduce imbalance finance of regional government, the Indonesian government gives financial support through the General Allocation Fund (GAF). At least, 26\% of whole state revenue is given to support regional governments. The amount is shared to all over provinces and districts/ cities in Indonesia. The sharing itself is based on regional needs and the potency of the area itself.

The implementation of fiscal decentralization policy in autonomy regional, as hoped, has brought a significant impact for regional governments, in this case, in Eastern Indonesia. This is seen through the Development Product Domestic Gross (DPDG) as well as the growing economy and community welfare. However, it is undeniable, what is hoped (das sollen) is not always in accordance with what is seen (das sein). There are still economic imbalance phenomena in Eastern Indonesia areas.

There are four factors that cause economic imbalance in Indonesia. They are (1) population distribution and uneven employment, (2) level of community welfare, (3) economic growth between regions, and (4) development of basic infrastructure between regions (Islam \& Khan, 1986). The phenomena of economic imbalance in Indonesia can be seen from data of the year 1990. By the year, the population in western Indonesia region covered $82 \%$ of the whole Indonesian population, while the eastern Indonesia region only covered $18 \%$. After 17 years, that is in 2007 , the total percentage of the population in western Indonesia only reduced by $1 \%$ while for Eastern Indonesia only increased by $1 \%$.

Furthermore, the imbalance level of social welfare is seen in the Human Development Index (HDI). HDI is one of the tools to measure that consists of three fundamental measurements namely; age level life, education level, and life standard level. Concept development of the human being developed by The United Nations establishes a ranking of the performance development for humans on a scale of $0.0-100.0$. It can be categorized as follows. High (HDI> 80.0); Middle class (HDI between 66.0 -79.9); Lower than middle class (HDI between 50.0 - 65.9); and lowest (HDI <50.0).

Related to the phenomena described above, the current research was conducted to the influence of fiscal decentralization policy towards economic growth in eastern Indonesia and (2) the influence of fiscal decentralization policy towards regional imbalances decline in eastern Indonesia.

\section{Materials and Methods}

In this section, we present the theory that is applied in the current study. Furthermore, we present the research method.

\subsection{Decentralization}

Decentralization is a tool for achieving aims of government, in this case, the Indonesian government, by providing better service that based on democratic values, it is a kind of shifting authority to the local/ regional government for managing expenditures and/or revenues.

Lamba, A., Allo, P., \& Lamba, R. (2019). Effect of fiscal decentralization policy of regional economic imbalances towards economy growth in Eastern Indonesia. International Journal of Social Sciences and Humanities, 3(2), 112127. https://doi.org/10.29332/ijssh.v3n2.298 
According to Bird (2013), decentralization is interpreted to mean the devolution of explicit authority and responsibility for a specific activity to a specific unit of government. Khusaini (2007), states that theoretically, there are some types of decentralization namely: politics decentralization, administrative decentralization, and fiscal decentralization. The implementation of decentralization is different. It is implemented in accordance with the characteristics of a country. The implementation, to be noticed, must be implemented perfectly.

However, even if decentralization is perfectly designed, some failures - breakdowns of service delivery, payment arrears, even extreme insolvency-may occur, so that there is always a need not only for the central government to maintain a sound macroeconomic framework (e.g., with respect to subnational borrowing) but also to develop and, if necessary, implement, the equivalent of a "bankruptcy" takeover of failed local governments.

Related to the current research, decentralization discussed here is about administrative decentralization. Administrative decentralization is an authority delegation intended for shifting authority, responsibility, and finance sources for providing better service. The delegation is especially concerned about planning, funding, and management functions.

Next, Khusaini (2007), states that administrative decentralization, basically, could be grouped into three forms namely: (1) Deconcentration as a kind of delegated authority from the higher official government to the lower official government who are working together for the central government. In deconcentration, all responsibility of planning and implementation or financing belong to the central government; (2) Devolution as a kind of delegated authority or power to a lower level, especially by the central government to the local or regional administration. In devolution, the central government does not take control of the local government. Whenever the government is not yet fully able to do its duty, the central government will do indirect supervision; (3) Delegation as the full authority shifting from the delegation giver to delegation receiver.

\subsection{Growth}

In the current research, the concept of growth is related to economic growth. According to Jhingan (2004), economic growth is "the process whereby the real per capita income of a country increases over a long period of time". He argued that economic growth is measured by the increase in the number of goods and services in each successive time period. Thus, growth occurs when an economy's productive capacity increases which are used to produce more goods and services. The definition has got three components namely, (1) The economic growth of a nation can be seen from the increasing inventory of goods; (2) Technological progress is an economic growth factor that determines the degree of growth in the ability to provide a variety of goods to all residents; and (3) The widespread use of technology requires adjustments in the institutional so that the resulting innovations can be utilized appropriately. Based on the thoughts described above, it is clear that GDP is a reflection of the performance economic growth, so that the output of goods and services can meet the demand of government.

\subsection{Regional Imbalance}

The problem of economic imbalance has started to be serious attention in the 1950s, that is when Kuznets introduced inverse U hypothesis between GDP per capita and imbalance in income distribution. It means that as an economy develops, market forces first increase and then decrease economic imbalance. Following is the figure of the curve that provides information about the hypothesis of Kuznets. 


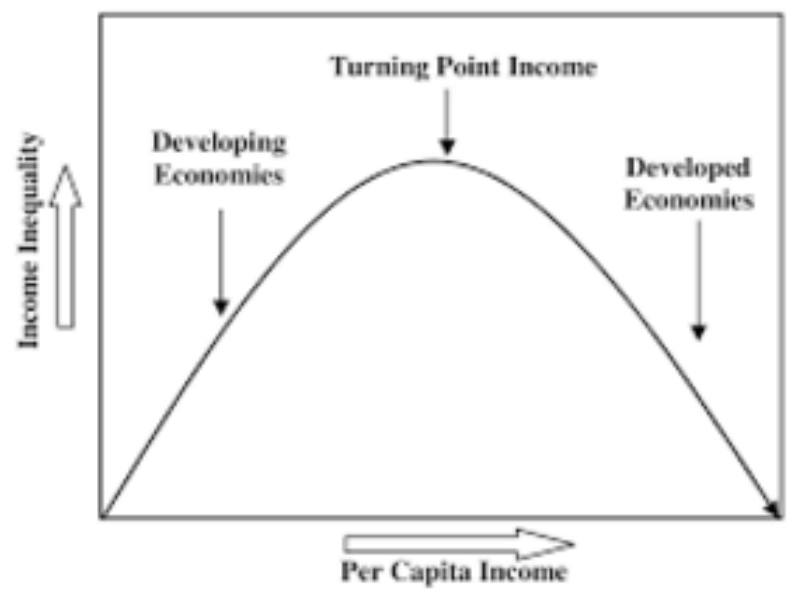

Figure 1. The Curve of Kuznets Hypothesis

Suppose that the Kuznets hypothesis, as described above, is correct, that economic development could reduce income imbalance, then the developing countries do not need to worry. A country like Indonesia, who faces high-income imbalance, do not need to be afraid. Furthermore, economists have conducted a lot of researches to see the relationship between imbalance income and economic growth. The results of the researches are varied. Some researches conducted previously have shown a negative relationship, while some others have shown a positive relationship between imbalance income and economic growth.

The result of the study conducted by Barro (1996), has shown that a high imbalance has been an inhibitor for growth in poor countries. In contrast, it supports growth in rich countries. Perroti (2016), has also conducted a study and has shown that that injustice of political level, as well as education level and the level of birth in a country, has impacted negative relationship towards distribution income and economic growth of a country.

In his book, Arsyad (2004), states that there are 7 factors that cause imbalance distribution income in moderate develop countries, namely: (1) The increase of population could decrease per capita income; (2) Inflation; (3) Imbalance development; (4) A high level of investment which causes imbalance of revenue percentage; (5) Low social mobility; (6) The implementation of substitution industry; and (7) The bankrupt industry.

\subsection{Concept of Framework}

There were results of several types of research that stated that through dynamic effect, decentralization fiscal can push economic growth, as well as reduce the regional imbalance. However, the results cannot be a basis of measuring as well as explaining the real condition of the performance development economy regionally. This is caused by some specific condition which is not always the same as another condition in other regions. Therefore, this research was conducted to examine the statement with a specific condition. In order to meet the aims, the researchers used a conditional variable, that is to obtain a group of information as an explanatory / control variable (Levine \& Renelth, 1992; Akai \& Sakata, 2005). The variable was implemented for explaining relationship pattern between variables, namely: variable of economy growth and variable of regional imbalance.

Control variables that can be identified as a variable determinant of economic growth and regional imbalance are described as follows: (1) Quality level of HR; This variable is measured from the level of education. This variable is a part of human capital investment. It has got a positive effect on the growing economy and regional imbalance (Barro \& Sala-I-martin, 2000; Akai \& Sakata, 2005; Hadi et al., 2018; Sumtaky et al., 2018). (2)Effect of economic stability; This variable is measured by examining the level of unemployment (Akai \& Sakata, 2005; Lisa \& Hermanto, 2018; Ghosh, 2017). (3) Level of Investment; This variable is obtained through real ratio gross of investment domestic from private and public companies

Lamba, A., Allo, P., \& Lamba, R. (2019). Effect of fiscal decentralization policy of regional economic imbalances towards economy growth in Eastern Indonesia. International Journal of Social Sciences and Humanities, 3(2), 112127. https://doi.org/10.29332/ijssh.v3n2.298 
towards real GDP I / Y. The coefficient is estimated to produce a positive relationship between investigation and economy growth and has got a negative relationship related to regional imbalance (Barro \& Sala-I-martin, 2000). (4) Residents Growth; This variable has got a negative effect on the steady-state condition of labor output activity towards residents growth (Barro \& Sala-I-martin, 2000). (5) GDP growth per capita; This variable has got a positive effect in a short period. However, in a long period, it correlates negatively towards regional imbalance (Kuznets, 1955; Pemayun \& Suderana, 2019).

\subsection{Research Method}

There were two main variables that applied in the current research. They were (1) variable of fiscal decentralization and (2) Character of the regional economy as a control variable. The variable of fiscal decentralization is a balanced fund that includes Specific Allocation Fund, Sharing Fund, and the General Allocation Fund.

Next, they were submitted as an equation of independent regression for examining the impact of fiscal decentralization towards economic growth and imbalance. According to Akai and Sakata (2005), fiscal decentralization contributes to economic growth as well as reducing imbalance that is $a_{1}>0$. A number of regional economy character which is called an explanatory variable or control variable is shown in the following table.

Table 1

Definition and variable measurement

\begin{tabular}{cll}
\hline No & Variable & Variable Measurement \\
\hline (1) & $(2)$ & $(3)$ \\
\hline 1. & Regional Economy Growth (REG) & Percentage of the constant price of annual GRDP growth \\
2. & Regional Imbalance (RI) & Willamson GRD constant imbalance using method Index of \\
& & Province population growth (\%) per year \\
3. & Population (PDDK) & Number of school participation (\%) per year \\
4. & Education Level (PDN) & The unemployment rate (\%) per year \\
5. & Unemployment & The ratio of investment towards PDRB per year \\
6 & Investment Level (IL) & Rationof Funds \\
7 & Fiskal desentraliataion (FD) & \\
\hline
\end{tabular}

\section{Method of Data Analysis}

Method of data analysis applied in the current research was the method of panel data analysis. Data in panel substantial was expected to be able to reduce omitted-variables. Besides that, it could resolve the correlation between free variables which could result in not-exactly assessment regression. Furthermore, in the estimation of an econometric model, the deeper analysis was conducted. This was conducted used regression effect through three techniques previous, namely: (1) Pool Least Square (PLS), (2) Fixed Effect Model (FEM) technique, and (3) Random Effect Model (REM) Technique. REM is a variation from the estimation of Generalized Least Square (GLS).

After that, the best model was chosen using F-test criteria and the Hausman test. F-test was used for choosing the best technique between PLS and FEM. The formula of F-test is as follows:

$$
\begin{aligned}
F & =\frac{\left(R^{2} u r-R \frac{2}{r}\right)(m)}{\left(1-R^{2} u r /\right)(n-k)} \\
R \frac{2}{r} & =\mathrm{R}^{2} \text { is a PLS model } \\
\mathrm{R} \frac{2}{u r} & =\mathrm{R}^{2} \text { is model of Fixed Effect }
\end{aligned}
$$


$\mathrm{m}$ = number of restricted variable

$\mathrm{n} \quad$ = number of sample

$\mathrm{k} \quad$ = number of the explanatory variable

Restricted variable (r) and unrestricted regression (ur) respectively refer to results estimation that PLS is better than FEM by using basic hypothesis. Next, The Hausman Specification Test was based on Chi-Square distribution. With basic thought above, the researchers present an adapted data analysis model used Levina \& Renelyh (2012); Akai \& Sakata (2005), and Xie et al., (1999), as follows:

a) Equation model of fiscal decentralization of regression effect toward economy growth

$$
P E R_{i t}=\propto_{0}+\propto_{0} F D_{i t}+\propto_{1} P D D K_{i t+} \propto_{2} A P S \quad+\propto 3 T P T_{i t+\propto_{4} T I_{i t+}} i \omega t
$$

b) Equation model of fiscal decentralization of regression effect toward regional imbalance

$$
K R_{i t}=\beta_{0}+\beta 1 F D_{i t}+\beta 1 P E R_{i t}+\beta 1\left(P E R_{i t}\right) 2+\beta_{2 P D D K_{i t}+\beta 3 A P S_{i t}}+\beta 4 T P T_{i t+\beta 5 T I} i \omega t
$$

"I" is a regional area while "T" is period time, control variables included some variables of po pulation growth (PDDK) and level of investment level (IL) variable. The research was conducted from 2001 to 2010 . It covered 16 provinces. In other words, there were 160 data observations for ten years.

In equations (1) and (2), it is explained as follows:

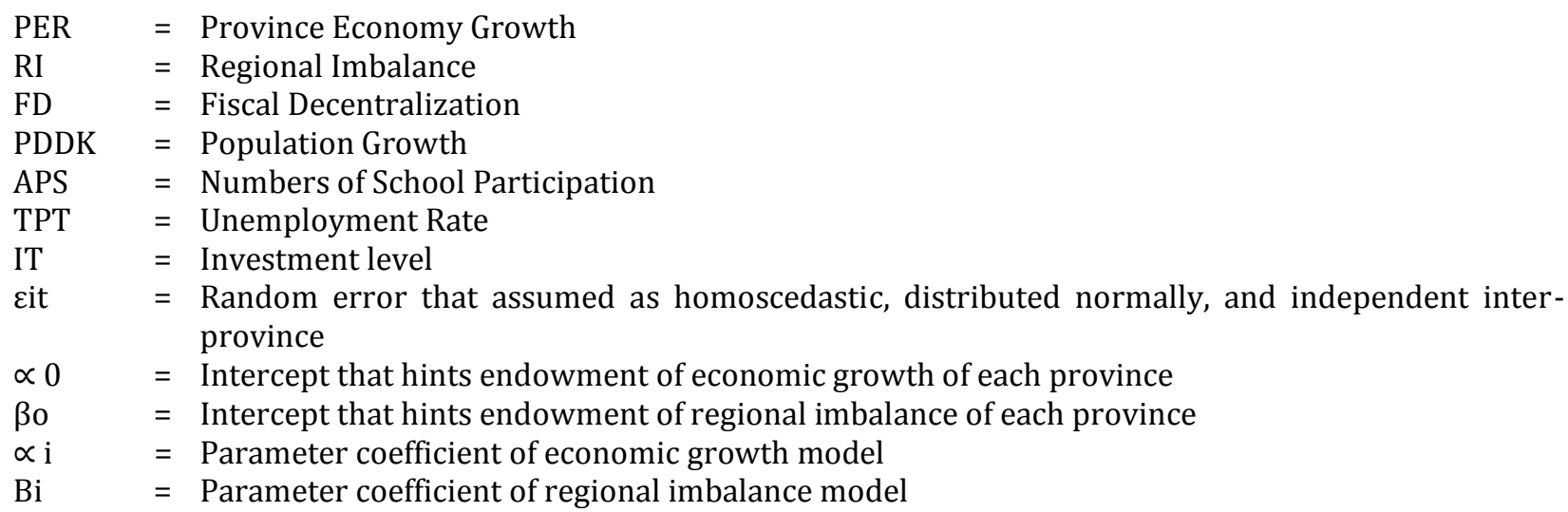

Next, in the equation of model b, there are two PER variables, namely PER and (PER) ${ }^{2}$ models quadratic. This model was meant to test Kuznets's hypothesis about the relationship between imbalance and growth economy that follows the U- reverse model. Kuznets's hypothesis could be accepted when the coefficient of the variable $(\mathrm{PER})^{2}$ is marked negative.

Besides that, for determining the level of regional imbalance, the researchers used Williamson Index (WI), namely:

$$
I W=\frac{\sqrt{\sum i(\dot{\bar{\gamma} l}-\bar{\gamma}) 2 \frac{\rho i}{\rho}}}{\bar{\gamma}} .
$$

Williamson Index (IW),

$\rho \mathrm{i} \quad=$ residents in the area

$\mathrm{I}, \mathrm{P}=$ total population

$\bar{\gamma} \quad=$ per capita income province

i, $\bar{\gamma}=$ average of per-capita income for Eastern Indonesia

Lamba, A., Allo, P., \& Lamba, R. (2019). Effect of fiscal decentralization policy of regional economic imbalances towards economy growth in Eastern Indonesia. International Journal of Social Sciences and Humanities, 3(2), 112- 


\section{Results and Discussions}

\subsection{Decentralization Fiscal Impact on Regional Economy Growth}

By applying REM technique, the analysis of research data has proven that the policy of decentralization impacts the enhancement of regional economic growth. The statement could be explained as follows.

\section{Intersep Value and Actual Value of 'Per-Capita Province GRDP'}

Based on the data analysis, it is obtained that the value of intercept is 1.113530 . The value is significant in 99 percent confidence. It is interpreted that by relying on the economic potential source of East Indonesia territory, the performance of the regional economy can be increased 1.11 percent. The finding is supported by the value of actual internship which describes the average value of the economic potential source prediction in each province. The value itself push regional economic growth. The following figure shows the average values of the economic potential source from 16 provinces in eastern Indonesia.

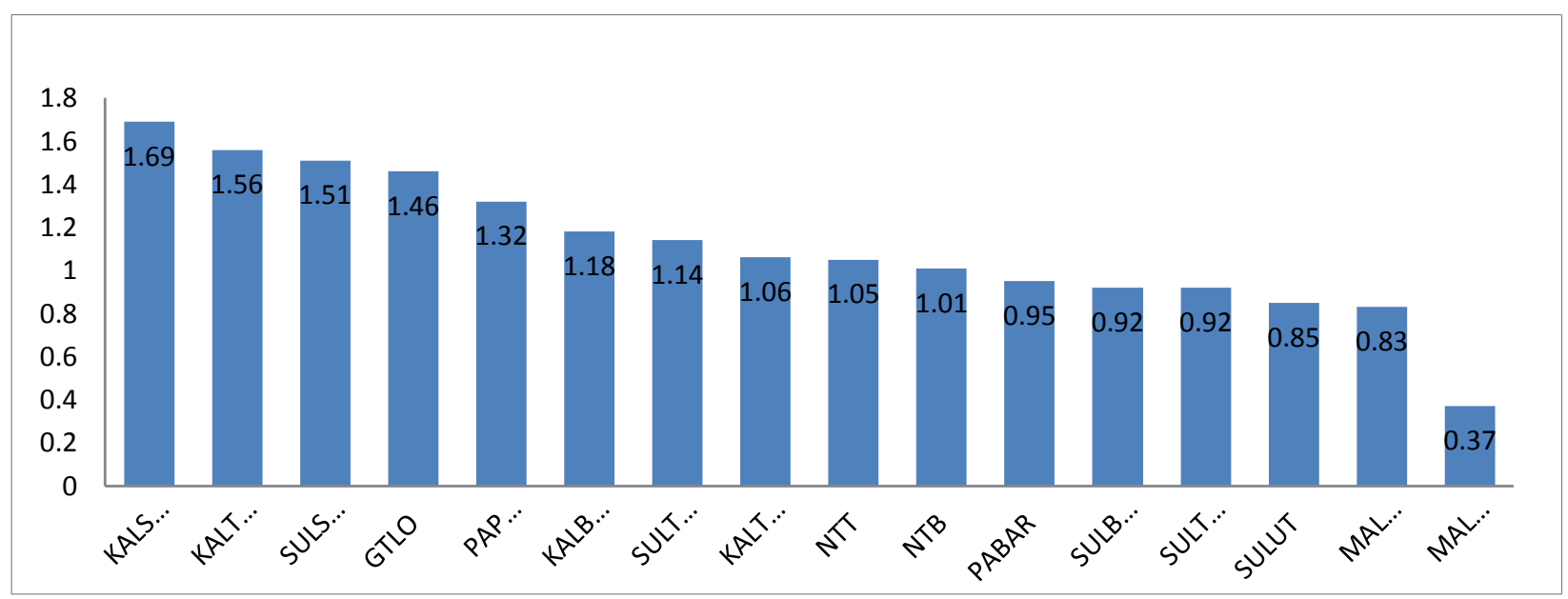

Figure 2. Values of The Economic Potential Source From 16 Provinces in Eastern Indonesia

$$
\begin{aligned}
\text { KALS } \ldots & =\text { South Kalimantan } \\
\text { KALT } \ldots & =\text { East Kalimantan } \\
\text { SULS... } & =\text { South Sulawesi } \\
\text { GTLO... } & =\text { Gorontalo } \\
\text { PAP... } & =\text { Papua } \\
\text { KALB } \ldots & =\text { West Kalimantan } \\
\text { SULT } \ldots & =\text { Southeast Sulawesi } \\
\text { MAL } . . . & =\text { Maluku }
\end{aligned}
$$

$$
\begin{array}{ll}
\text { KALT } \ldots & =\text { Middle Kalimantan } \\
\text { NTT } & =\text { East Nusa Tenggara } \\
\text { NTB } & =\text { West Nusa Tenggara } \\
\text { PABAR } & =\text { West Papua } \\
\text { SULB } \ldots & =\text { West Sulawesi } \\
\text { SULT } \ldots & =\text { Southeast Sulawesi } \\
\text { SULUT } & =\text { North Sulawesi } \\
\text { MALUT } & =\text { North Maluku }
\end{array}
$$

The above figure shows that the average values of the economic potential source from 16 provinces in eastern Indonesia are different in the structure of the province economy. The high value of economy potency that is higher than 1.5 percent ( $>1.5 \%$ ) owned by the provinces of South Kalimantan, East Kalimantan, and South Sulawesi. Next, the provinces that classified as the moderate value of economy potency (1.00 - 1.49) owned by Gorontalo, Papua, West Kalimantan, Central Sulawesi, Central Kalimantan, East Nusa Tenggara, and Nusa Tenggara. While provinces with the low classification (0.50-0.99) included West Papua, West Sulawesi, North Sulawesi, and North Maluku. Finally, the lowest value of economy potency owned by Maluku (0.00 to 0.49 ). 
The different values are influenced by the different policy of decentralization. That means that the higher the level of decentralization, the more management activities of regency economy development is conducted. An indicator for measuring the level of decentralization is from the economy source of each regency, especially from original sources funds.

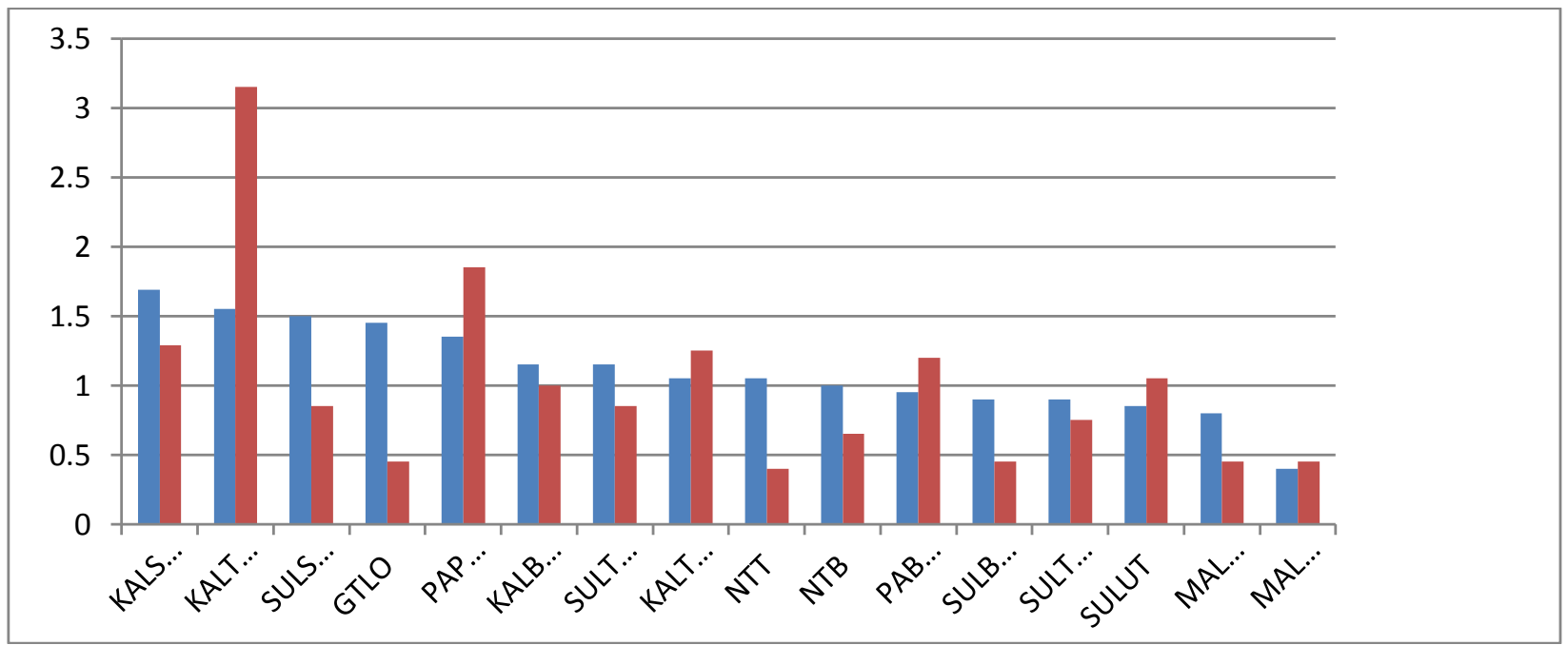

Figure 3. Comparison of Potential Values Power Source and Actual Value of "Per-Capita GRDP" in the provinces of Eastern Indonesia

From the above figure, it is known that the average value of potency source (blue bars) is higher than actual GRDP per capita (red bars). This means that the economic potency of provinces in Eastern Indonesia has not explored optimally. The potency source, in this research, is not only about natural sources, but also human resources (as seen from the level of education). Eastern Indonesia people, based on the level of their education, can create innovations in new development economy area, especially related to the management sources.

In other side, provinces in Eastern Indonesia, generally, have different levels of resource factors. Therefore, the management and utilization of sources of income are not only about the responsibility of the local government but also become part of the responsibility of the central government, especially in areas of low economic production factors with limitations in the financial sector.

Because the problem of limited funds in financing development activities in the regions is a source of increasing fiscal inequality between regions, the implementation of fiscal decentralization policies is important. It is one of the instruments to reduce fiscal imbalances. The results of this study have also proven that the central government of Indonesia has tried to reduce the impact caused by fiscal imbalance. Over the past ten years, from 2009-2018, funds allocated by the central government to local governments has increased namely, on average 20.86 percent or Rp9.84 trillion per year.

Therefore, the Indonesian Government has revised the regional budget structure. One of the revisions is to provide the largest proportion of direct expenditure. This is intended to create a better public service system and encourage regional economic performance.

Decentralized fund fiscal allocated to local regency is intended for reducing the fiscal imbalance. Following is the figure that shows the relationship between Fiscal Decentralization Funds (FDF) and "per-capita GRDP". The figure itself is the statistical analysis conducted by researchers.

Lamba, A., Allo, P., \& Lamba, R. (2019). Effect of fiscal decentralization policy of regional economic imbalances towards economy growth in Eastern Indonesia. International Journal of Social Sciences and Humanities, 3(2), 112- 


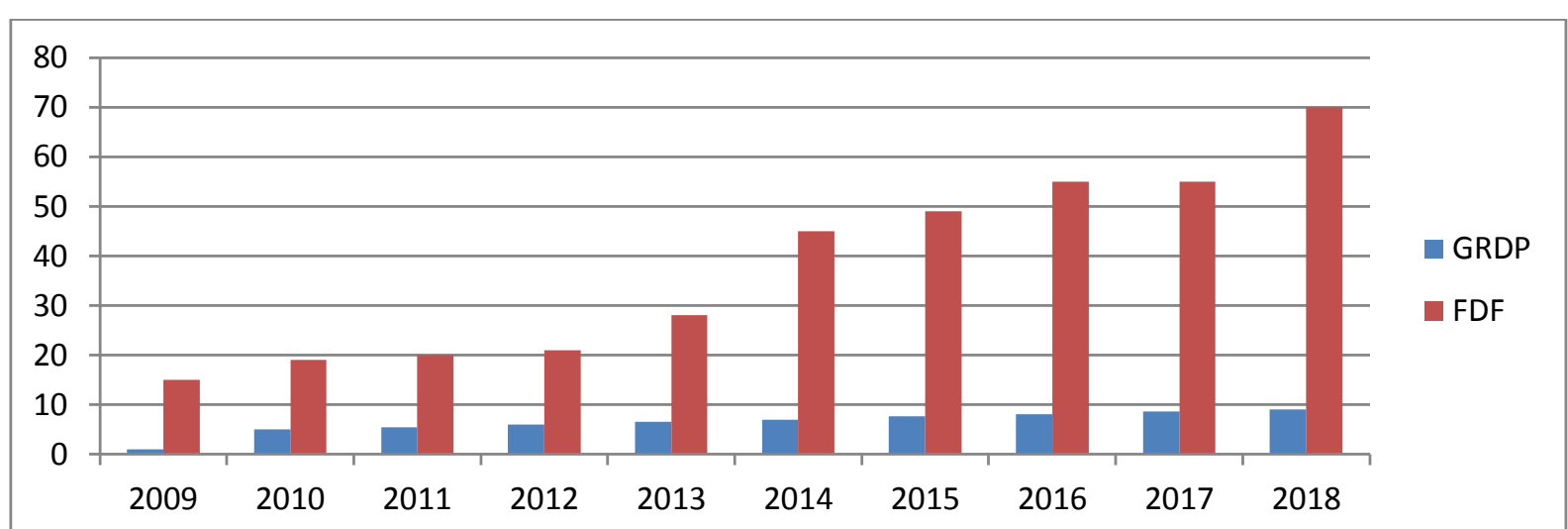

Figure 4. The Average Fiscal Decentralization Fund (FDF) and Per Capita GRDP in East Indonesia, 2009-2018 Source: Statistical Analysis

Number in the above figure confirms that fiscally decentralized fund allocated through the Balancing Fund (BF) has increased as much as 20.86 percent. Likewise, the income of GDP per capita has also increased by 20.41 percent per year. However, the question is whether the increase in GDP per capita as an indicator of economic performance is more to indirect regional expenditure (IRE) or direct regional expenditure (DRE). The following figure explains the relationship between IRE and DRE as well as income of GRDP per-capita. The following figure explains the relationship between BTL, BL and the GDP per capita income.

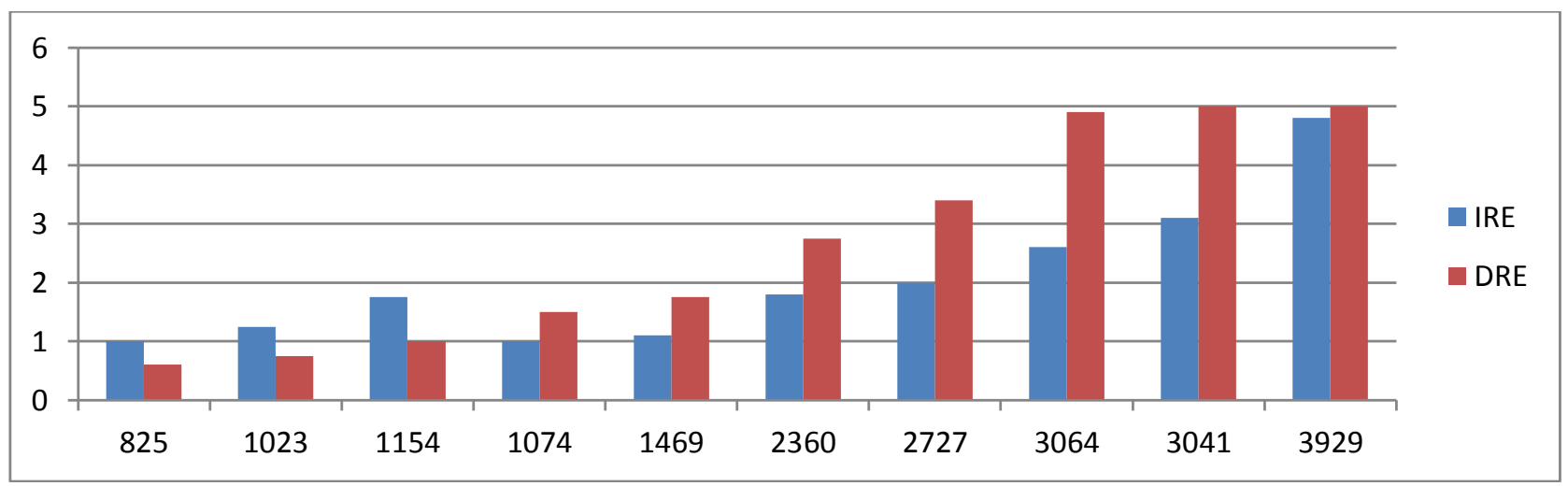

Figure 5. The Relationship between BTL, BL and the GDP Income Per-Capita Source: Statistical analysis, 2009-2018

The above figure shows that during 2009-2018 regional expenditure continued to show an increase from year to year for both IRE and DRE. The average increase per year for each of them is $22.44 \%$ and $28.21 \%$. The increase in the IRE and DRE directly affected the increase in per-capita GRDP income. The extent of them has affected the movement of GDP per capita.

Furthermore, the image above also confirms that IRE is more elastic compared to DRE. The increase in percapita GRDP is more influenced by indirect expenditure IRE, especially on personnel expenditure. While DRE, which is expected to encourage economic growth through public service investment, is relatively insignificant or more inelastic. Even though direct expenditure, through capital expenditure, is expected to be a stimulus to increase regional economic growth, the reality has not yet reached the target as expected. This is due to the fact that most decentralized funds allocated to finance regional economic development activities, especially indicated capital expenditure, are mostly used to finance unproductive development activities. Only a small portion is used to finance productive economic development activities.

Changes in the budget structure impact on the condition of the future regional economy. The impact can be negative or positive. It depends on determining the priority scale to create equitable development. Undeniable, the goal of creating efficient development is sometimes neglected so that it has a negative impact 
on people's welfare. Vice versa, if the priority scale is on efficiency aspects, then the aspect of development mapping is neglected. These two objectives should be the basis for regional governments in the framework of autonomization and decentralization.

Local governments are required to be careful in determining and implementing development policies without having to override another region. This is the main core of the Decentralization Theorem, which Akai \& Sakata (2005), said, that; every consumption of public goods is interpreted as a part of the geographical setting of the entire population, and each sacrifice generates benefits in each jurisdiction that is the same as the central government and/or every regional government will always be more efficient (or least efficient) so that it can reach the Pareto- efficient output level. This means that fiscal decentralization will have a positive impact because it can create levels of efficiency in various fields of development, especially related to the provision of better services to the community. By providing better services, other development activities will also be affected, to grow and develop, so that it will indirectly encourage local economic growth which is expected to improve community welfare.

Therefore, it is stated that the result of the current research has proved that fiscal decentralization has positively impacted regional economies of Eastern Indonesia. The increase of economy that impacted by fiscal decentralization is significant. The findings of the current research have supported the theory as well as empirical study about the effect of fiscal decentralization that has ever conducted by Akai \& Sakata (2005); Khusaini (2006); Wibowo (2008); and Feld \& Schnellenbach (2010).

\subsection{Impact of Fiscal Decentralization toward Regional Imbalance}

Theoretically, the implementation of fiscal decentralization is expected to have a positive impact on regional economic growth based on equitable income distribution and optimization of local government expenditure. However, the realization depends on the level of financial readiness of each region. The inability of the regions to allocate funds efficiently which is not supported by a good administrative system and the low power of redistribution of resources between regions within one province will hamper regional economic growth and development and can increase existing regional inequality. The result of the current research using the fixed-effect model (FEM) technique proves that the implementation of fiscal decentralization can reduce regional inequality. The discussion is presented as follows.

\section{Actual Value of Regional Gap}

In the current research, the actual value of the regional gap is something that describes the condition of imbalance in each province in East Indonesia region. The imbalance is a dummy variable that obtained from the difference between coefficient intercept and value intercept which are made as category reference or based match by each province. In the current research, Gorontalo, as an eastern province in Indonesia was counted as based match category. Gorontalo was the new province in Indonesia that was established together with the implementation of autonomization and decentralization policy in 2001; Furthermore, the coefficient variation (Williamson Index) of the province was relatively low for 0.24 compared to another province.

The result of the current study has also confirmed that the actual value of each province in the eastern Indonesia region is relatively low. This is evidenced by the actual value of regional inequality which shows an average of a negative number (except for the provinces of West Nusa Tenggara and East Kalimantan). It can be seen from the following figure which describes expanding territory in red bars, while the blue bars are the non-expanded territory.

Lamba, A., Allo, P., \& Lamba, R. (2019). Effect of fiscal decentralization policy of regional economic imbalances towards economy growth in Eastern Indonesia. International Journal of Social Sciences and Humanities, 3(2), 112- 


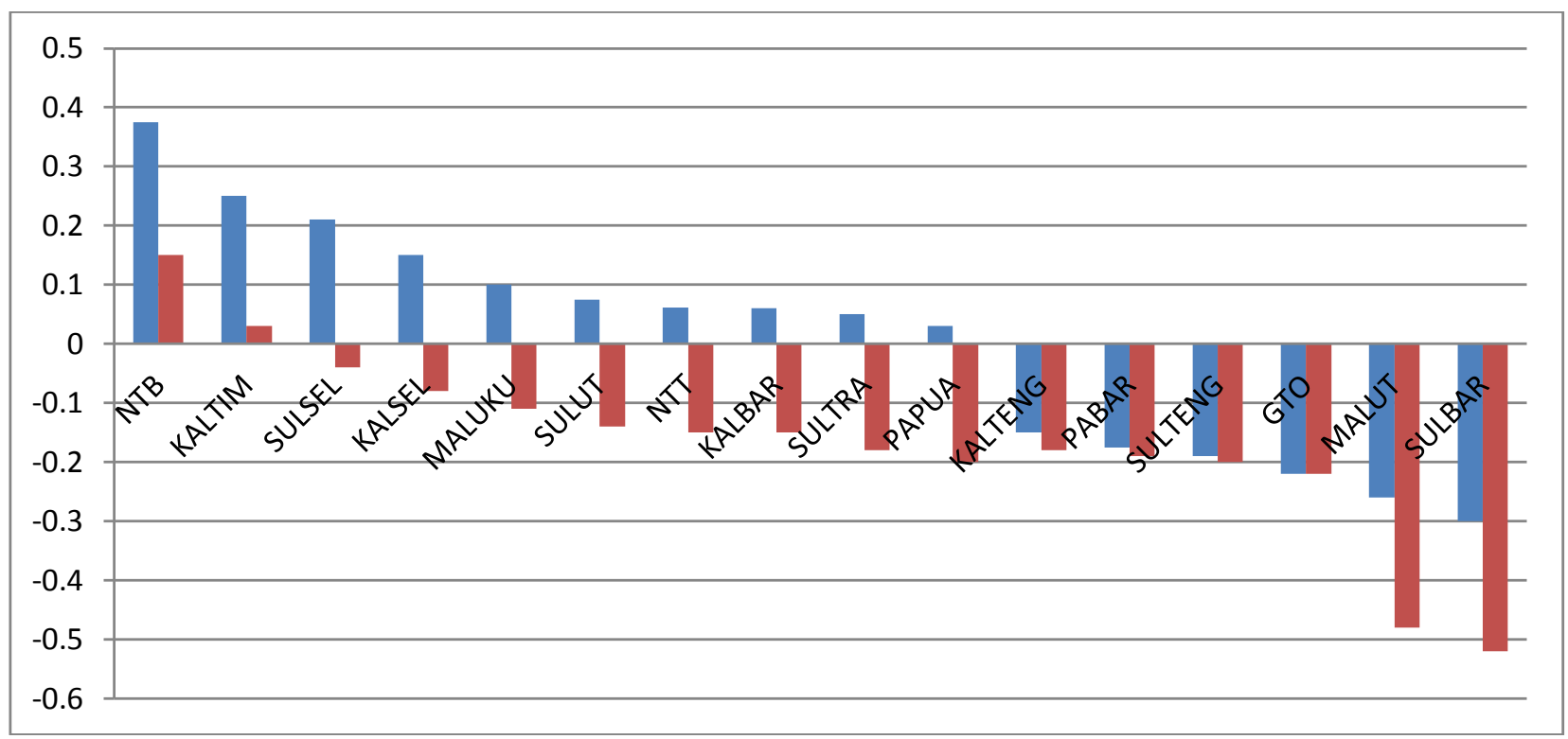

Figure 6. Comparison Value and Actual Intercept of Regional Imbalance Source: Processed Data Research

The data in the above figure shows a comparison between the value of intercepts and the actual value of regional inequality from each province. The province with the highest intercept value and the actual value of regional inequality in West Nusa Tenggara, while the province with the lowest intercept is West Sulawesi. This means that provinces with positive intercept values show a tendency to be more imbalanced in income distribution compared to other provinces. Provinces with positive intercept values include the prevention of West Nusa Tenggara, East Kalimantan, South Sulawesi, South Kalimantan, Maluku, North Sulawesi, West Nusa Tenggara, West Kalimantan, Southeast Sulawesi, and Papua. Provinces with negative intercept values include West Sulawesi, North Maluku, Gorontalo, Central Sulawesi, West Papua, and Central Kalimantan. The following figure (Figure 7) has also gained from the statistical process of the current research. The figure explains more related to the phenomena discussed.

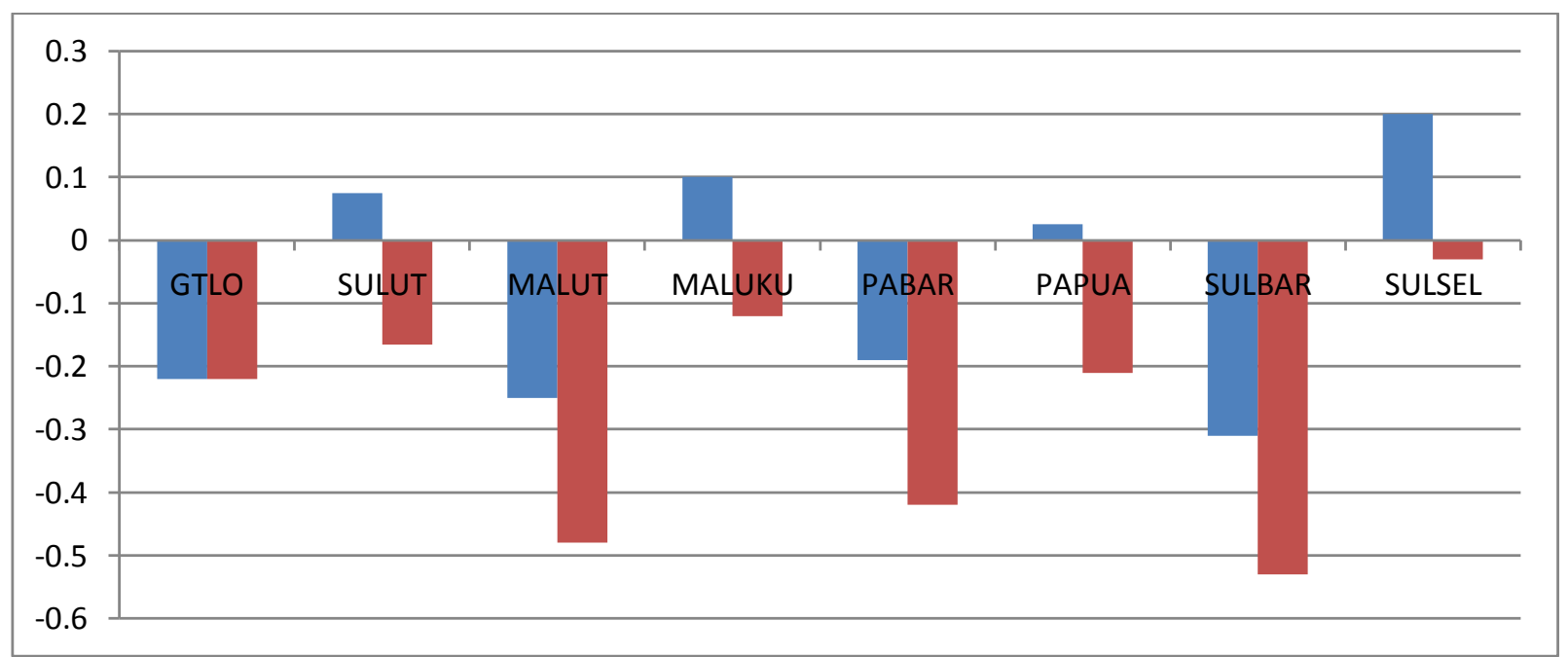

Figure 7. Comparison Value and Actual intercept Regional Imbalance of Expanded-Territory Provinces and Non-Expanded-Territory of Eastern Indonesia 


\section{Fiscal Decentralization and Regional Imbalance}

As explained previously, the implementation of fiscal decentralization is expected to impact economic growth positively. Therefore, funds allocation must be distributed efficiently and effectively. It should be supported by the good administration system as well as strength redistribution resource area. If the fund allocation is not effective, and the administration system is not good, then it can inhibit the growth of the economy, which is finally will also improve regional imbalance.

Based on the results of the current study, it is confirmed that the value of fiscal decentralization coefficient is negative as much as 0.024790 . This implies that when the allocation of funds transfer through regional government budget has decreased, regional inequality will increase by 0.024790 or 0.02 percent. Conversely, if allocated transfer funds show an increase, it will be followed by a decrease in regional inequality. Although fiscal decentralization can reduce regional inequality, the relationship between the two variables is not significant.

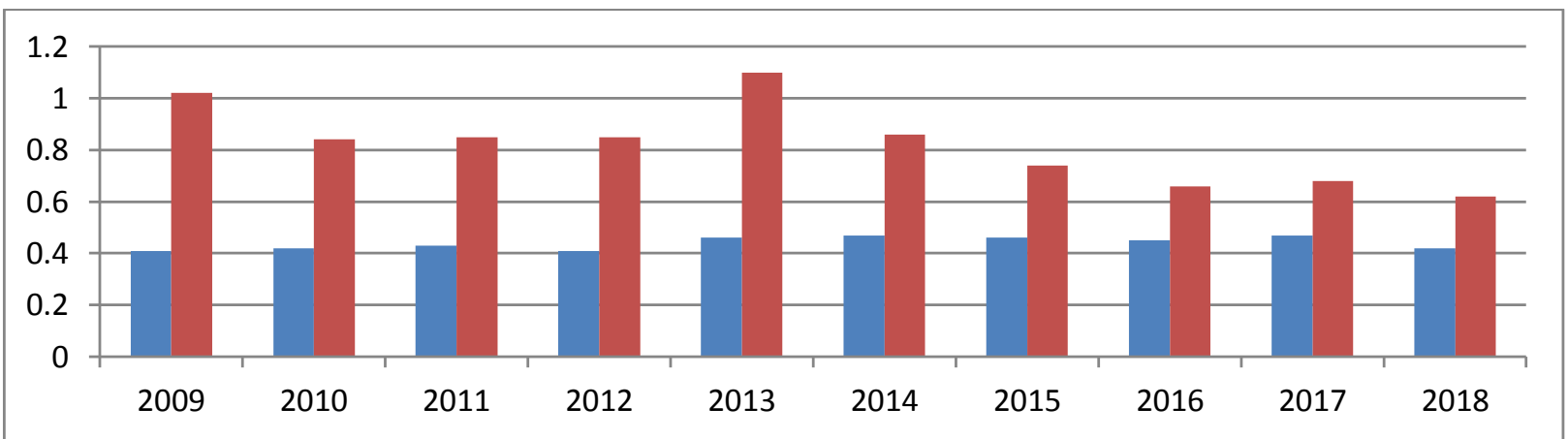

Figure 8. Relationship Decentralization Regional Fiscal and Imbalance

Figure 8 above shows the relationship between fiscal decentralization with regional imbalance measured with Williamson index. The blue bars present regional imbalance while the red bars present fiscal decentralization. It shows that the relationship is not consistent. In 2009-2011, when fiscal decentralization funds tended to fall, imbalance phenomena tended to increase. Then in 2012-2013, fiscal decentralization funds increased again. However, the imbalance also tended to increase. Furthermore, in 2014-2016, fiscal decentralization funds continued to show a decline. While the level of inequality is relatively more stable with an increasing tendency. Therefore, local governments need to be careful and give special attention to these symptoms. Although the percentage increase is relatively small, it has a significant impact on the continuity of future development. It can also be seen that the increase in the level of inequality is indicated as a result of the proportion of decentralized funds allocated to the regions due to the addition of funds to the newly created regions.

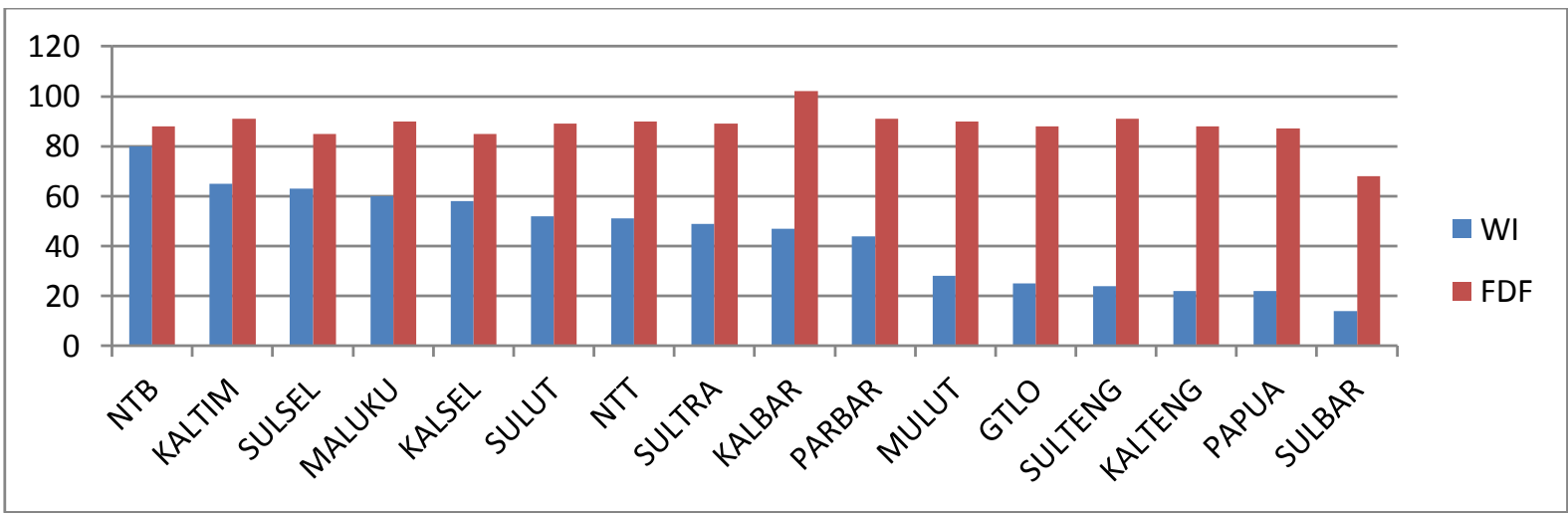

Lamba, A., Allo, P., \& Lamba, R. (2019). Effect of fiscal decentralization policy of regional economic imbalances towards economy growth in Eastern Indonesia. International Journal of Social Sciences and Humanities, 3(2), 112127. https://doi.org/10.29332/ijssh.v3n2.298 
Figure 9. Williamson Index (WI) and The Average Proportion of Fiscal Decentralization Fund (FDF)

The above figure shows the regional level of imbalance. The blue bars show the Williamson Index while the red bars show the average of Fiscal Decentralization Fund. Williamson index is relatively low, as much as 43.63 percent. However, on the other hand, the average proportion of fiscal decentralized funds to Regional Government Budget is high enough, as much as 87.40 percent. The province with the highest level imbalance is West Nusa Tenggara while the lowest in West Sulawesi. In the other side, the highest proportion of fiscal decentralization funds is West Kalimantan and the lowest is occupied by West Sulawesi province. The high fiscal decentralization funds allocated to the provinces indicate that the dependence on finance from the central government in financing regional economic development activities is relatively large. This means that there is a counter-active relationship between fiscal decentralization and regional inequality.

On the one hand, because the existence of regional financial dependence is still quite high, but the level of regional imbalance is relatively low. This phenomena impact the relationship between two variables to be quite low, which is at a negative 0.03 percent. This also means that fiscal decentralization does not have a significant influence to reduce regional inequality.

The cause of low or weak relations between fiscal decentralization and regional inequality is indicated by several factors. First, the decentralization fund allocation has not been able to meet the basic financial needs of the region because it is relatively low. Second, the allocation of government expenditures that are not on target or inefficiency in managing regional expenditure budgets since most are distributed to personnel expenditure and capital expenditure. For example, capital expenditure is expected to be able to finance productive economic activities, but more is used to finance activities that are less productive or consumptive. This is similar to the proposal of Canaleta et al., (2004). They state that the size of the public sector has got a positive relationship with regional inequality. Third, economic administration and institutional systems that are not well supported and organized. This makes the community difficult to carry out economic activities.

The relationship between fiscal decentralization and inequality, so far, has been a particular concern to most economists. Akai \& Sakata (2005), determined that the direction of the relationship between fiscal decentralization and regional inequality was highly dependent on how fiscal decentralization was promoted. There are two directions, namely (1) related to distribution or budget allocation, and (2) degree of autonomy. Furthermore, it is stated that local expenditure in fiscal decentralization does not have a significant effect on regional inequality, while the achievement of autonomy in fiscal decentralization has a negative effect on regional inequality. The findings of the current research are in accordance with the findings of previous researchers, especially related to the statement that (1) the allocation of budget expenditures is not on target, and (2) the administrative system and institutional instruments are the key to achieving decentralization.

In addition, the results of the current research are also in accordance with the research of Bonet (2006). Bonet (2006), states that behavior that low relationship between decentralization and regional inequality is caused by several factors, namely (1) current expenditure is mostly allocated to new regional resources (for example, wages and salaries), (2) the funds are not used for capital investment or infrastructure; (3) lack of components of national transfer redistribution; (4) the absence of adequate incentives from the national to the regional level to promote efficiency benefits; and (5) the lack of institutional capacity. Furthermore, important elements that need to be addressed in the implementation of fiscal decentralization that can affect regional inequality are fair transfer systems, the ability to select sectors to allocate resources, and the correct implementation of incentives. In the other side, the elements that need to be monitored are related to the level of economic openness and the tendency of economic agglomeration. Undeniable, they can cause regional inequality.

Thus, the finding of the current research supports the results of previous researches, that fiscal decentralization has got a negative relationship towards regional inequality. Furthermore, it also rejects other previous researches which state that fiscal decentralization has got a positive relationship, and not dangerous since it would further aggravate the regional economy, especially for developing countries (Rodriquez-Pose \& Ezcurra, 2010). 


\section{Conclusion}

Based on the results of the current research and discussion, two main important points can be summarized as follows. (1) Fiscal decentralization has an effect that can affect regional economic growth. This means that even though the allocation of transfer funds is relatively low, it is proven that it has the ability to encourage regional economic growth in Eastern Indonesia. This proves that the expenditure allocation used is appropriate to encourage economic growth. (2) The relationship between fiscal decentralization and regional inequality confirms that fiscal decentralization does not have the ability to reduce inequality in Eastern Indonesia. The inability of fiscal decentralization to reduce inequality is due to the fact that the regional budget allocations are mostly used not for public service purposes, but are used for government interests such as; salary, official travel, and office equipment.

Next, based on those two points, it is suggested some points as follows. The concept of autonomization and decentralization has been running for a decade, but the impact has not yet shown a clear direction. The allocation of transfer funds continues to show an increase every year, but it is not followed by the creation of better services to the community as a result of the regional economic performance not running in line with expectations, so what happens is regional inequality widens. Therefore, researchers suggest several things as follows:

1) To improve regional economic performance, the government needs to reconsider the number of funds allocated to regions in order to cover fiscal inequalities based on regional budget reforms, especially in regions or provinces that have limited regional economic resources so that they can encourage and enhance economic growth;

2) It is necessary to manage the regional budget and income efficiently and comply with good governance values. This means that the budget allocation of finance regional development activities must show a priority scale that really has implications for improving people's welfare.

3) Implementation of regional development policies needs to pay attention to factors related to population problems, school participation rates, and investment levels. These factors have greatly influenced economic growth and the creation of equitable regional development.

4) To encourage economic growth and reduce economic regional imbalance, the government needs to accelerate development in strategic areas that have the potential to grow quickly, that is by opening opportunities for cooperation with the private sector so that they can develop areas that are left behind. Provision of infrastructure is needed in order to encourage economic activities of local communities, especially small and medium-sized business activities.

5) For local governments, it is also necessary to have a strong commitment to providing optimal service to the community.

\section{Acknowledgments}

This work was supported by Universitas Cenderawasih Papua, Indonesia. Therefore, we would like to offer our grateful to the rector of Universitas Cenderawasih Papua, Indonesia.

Lamba, A., Allo, P., \& Lamba, R. (2019). Effect of fiscal decentralization policy of regional economic imbalances towards economy growth in Eastern Indonesia. International Journal of Social Sciences and Humanities, 3(2), 112- 


\section{References}

Akai, N., \& Sakata, M. (2005). Fiscal decentralization, commitment and regional inequality: evidence from statelevel cross-sectional data for the United States (No. CIRJE-F-315). CIRJE, Faculty of Economics, University of Tokyo.

Arsyad, L. (2004). Ekonomi Pembangunan, Bagian Penerbitan STIE YKPN.

Barro, R. J. (1996). Determinants of economic growth: A cross-country empirical study (No. w5698). National Bureau of Economic Research.

Barro, R. J. (1996). Determinants of economic growth: A cross-country empirical study (No. w5698). National Bureau of Economic Research.

Bird, R. M. (2013). Local taxes and local expenditures: Strengthening the Wicksellian connection.

Bonet, J. (2006). Fiscal decentralization and regional income disparities: evidence from the Colombian experience. The Annals of Regional Science, 40(3), 661-676. https://doi.org/10.1007/s00168-006-0060-z

Canaleta, C. G., Pascual Arzoz, P., \& Rapun Garate, M. (2004). Regional economic disparities and decentralisation. Urban Studies, 41(1), 71-94. https://doi.org/10.1080/0042098032000155696

Feld, L. P., \& Schnellenbach, J. (2010). Fiscal Federalism and Long-Run Macroeconomic Performance (No. paper1009). International Center for Public Policy, Andrew Young School of Policy Studies, Georgia State University.

Ghosh, C. (2017). A study on - evaluating marketing strategies adopted by home appliance for economic development in India. International Journal of Social Sciences and Humanities, 1(1), 9-15. https://doi.org/10.29332/ijssh.v1n1.7

Hadi, A., Handajani, L., \& Putra, I. N. N. A. (2018). Financial Disclosure based on Web-ICT Determinants: Its Implications for Local Government Financial Performance in Indonesia. International Research Journal of Management, IT and Social Sciences, 5(1), 72-85.

Islam, I., \& Khan, H. (1986). Spatial patterns of inequality and poverty in Indonesia. Bulletin of Indonesian Economic Studies, 22(2), 80-102. https://doi.org/10.1080/00074918612331334834

Jhingan, M. L. (2004). Ekonomi pembangunan dan perencanaan. Jakarta: PT. Raja Grafindo Persada.

Khusaini, K., Lestari, S., \& Agustin, N. A. (2018). The Application of Problem-Based Learning Methods to Improve Economic Learning Outcomes and Motivation. Dinamika Pendidikan,13(2), 218-227. https://doi.org/10.15294/dp.v13i2.16634

Khusaini, M. (2015). A shift-share analysis on regional competitiveness-a case of Banyuwangi district, East Java, Indonesia. Procedia-Social and Behavioral Sciences, 211, 738-744. https://doi.org/10.1016/j.sbspro.2015.11.097

Kuznets, S. (1955). Economic growth and income inequality. The American economic review, 45(1), 1-28.

Levina, N., Tötemeyer, S., Stokes, N. R., Louis, P., Jones, M. A., \& Booth, I. R. (1999). Protection of Escherichia coli cells against extreme turgor by activation of MscS and MscL mechanosensitive channels: identification of genes required for MscS activity. The EMBO journal, 18(7), 1730-1737.

Levine, R., \& Renelt, D. (1992). A sensitivity analysis of cross-country growth regressions. The American economic review, 942-963.

Lisa, O., \& Hermanto, B. (2018). The effect of tax amnesty and taxpayer awareness to taxpayer compliance with financial condition as intervening variable. International Research Journal of Management, IT and Social Sciences, 5(2), 227-236.

Pemayun, A. A. G. P., \& Suderana, I. W. (2019). Shifting social and economic structural community: rapid development of tourism sector. International Journal of Social Sciences and Humanities, 3(1), 115-124. https://doi.org/10.29332/ijssh.v3n1.271

Perotti, R. (1996). Growth, income distribution, and democracy: What the data say. Journal of Economic growth, 1(2), 149-187.

Perotti, V., Baldassari, P., Molla, A., Vegetti, C., Bersani, I., Maurichi, A., ... \& Mortarini, R. (2016). NFATc2 is an intrinsic regulator of melanoma dedifferentiation. Oncogene, 35(22), 2862.

Rodríguez-Pose, A., \& Ezcurra, R. (2010). Is fiscal decentralization harmful for economic growth? Evidence from the OECD countries. Journal of Economic Geography, 11(4), 619-643. https://doi.org/10.1093/jeg/lbq025 
Sumtaky, M., Chandrarin, G., \& Sanusi, A. (2018). Effect of elements of regional financial management towards SKPD regency/city performance and its implication on public service. International Research Journal of Engineering, IT \& Scientific Research, 4(2), 73-86.

Wibowo, P. (2008). Mencermati dampak desentralisasi fiskal terhadap pertumbuhan ekonomi daerah. Jurnal Keuangan Publik, 5(1), 55-83.

Xie, D., Zou, H. F., \& Davoodi, H. (1999). Fiscal decentralization and economic growth in the United States. Journal of Urban economics, 45(2), 228-239. https://doi.org/10.1006/juec.1998.2095

\section{Biography of Authors}

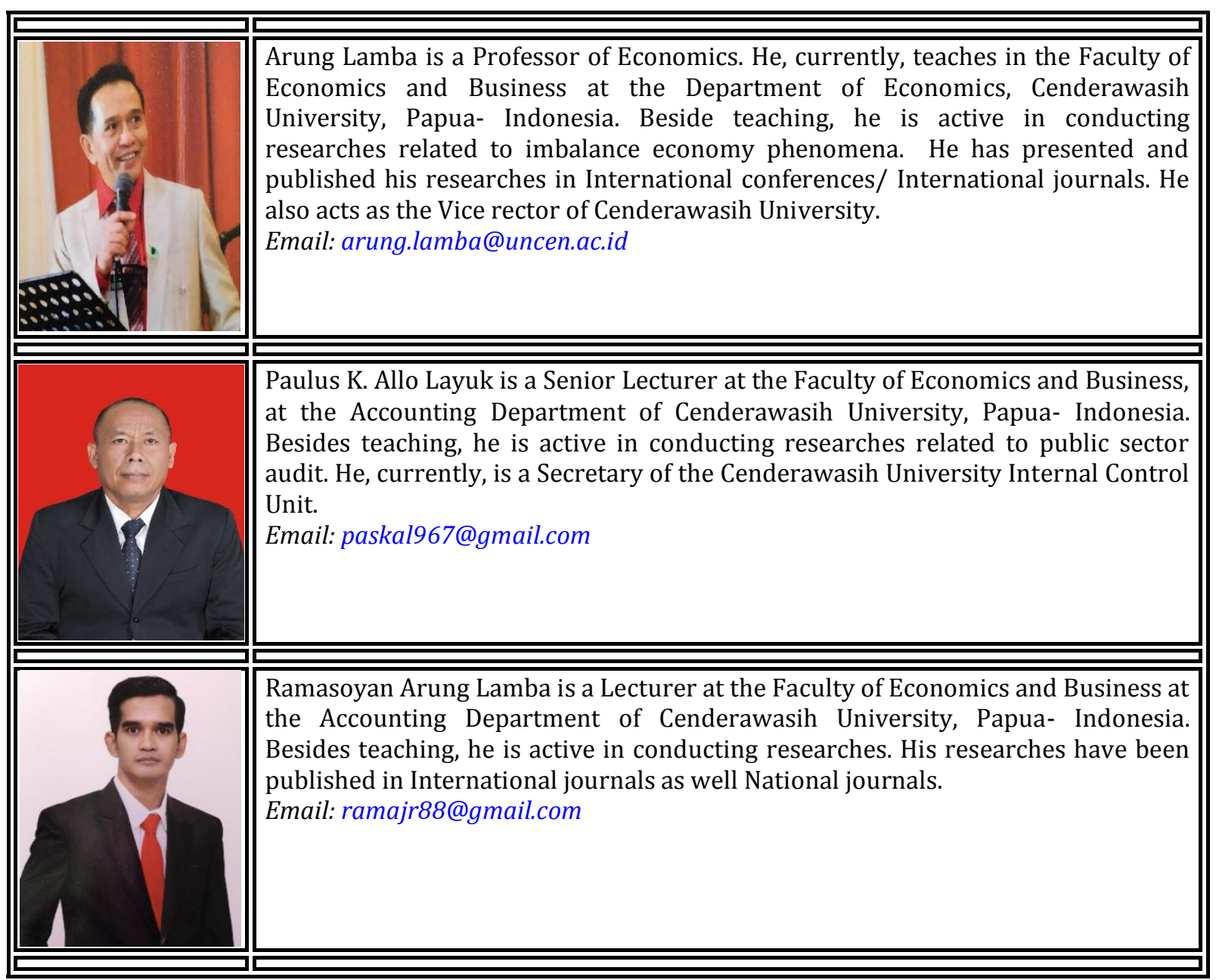

Lamba, A., Allo, P., \& Lamba, R. (2019). Effect of fiscal decentralization policy of regional economic imbalances towards economy growth in Eastern Indonesia. International Journal of Social Sciences and Humanities, 3(2), 112- 